\title{
Interception of solar radiation by the productive structures of spring canola hybrids
}

\author{
Interceptação de radiação solar pelas estruturas reprodutivas de híbridos de canola de primavera
}

\author{
Elizandro Fochesatto ${ }^{\text {I }}$ Astor Henrique Nied ${ }^{\text {II }}$ Homero Bergamaschi ${ }^{\text {III }}$ Genei Antonio Dalmago ${ }^{\text {IV }}$ \\ Daniele Gutterres Pintov ${ }^{\mathrm{V}}$ Samuel Kovaleski ${ }^{\text {VI }}$ Gilberto Roca da Cunha $^{\text {IV }}$ Jorge Alberto Gouvea $^{\text {IV }}$
}

\section{ABSTRACT}

The objective of this study was to adjust parameters related to the interception of photosynthetically active radiation (PAR) by reproductive structures of spring canola, with different nitrogen levels and hybrids. Two field experiments were conducted, being one with different sowing dates and hybrids (Hyola 61 and Hyola 432) and another with doses of 10, 20, 40,80, 160kg hat of $N$, applied in top dressing. They were conducted in Passo Fundo and Coxilha, RS, Brazil, in 2011 and 2014, respectively.The evaluated variables were: area index of reproductive structures, interception efficiency and extinction coefficient of these structures for PAR. PAR interception increased by increasing the reproductive structures volume. Interception efficiency of PAR by reproductive structures ranged from 45 to $80 \%$. It was higher in the Hyola 61 hybrid and at the highest dose of $N$. The extinction coefficient of reproductive structures for PAR was 0.44 in non-limiting doses of $N$.

Key words: Brassica napus, interception efficiency, extinction coefficient, silique.

RESUMO

$O$ objetivo deste estudo foi parametrizar a interceptação de radiação fotossinteticamente ativa (RFA) pelas estruturas reprodutivas de canola de primavera, em função de doses de nitrogênio e híbridos. Dois experimentos de campo foram conduzidos, sendo um com diferentes hibridos (Hyola 61 e Hyola 432) e outro com doses de $\mathrm{N} \mathrm{de} \mathrm{10,20,40,80,} 160 \mathrm{~kg} \mathrm{ha}^{-1}$, aplicadas em cobertura. Eles foram conduzidos em Passo Fundo e Coxilha, RS, Brasil, em 2011 e 2014, respectivamente. As variáveis avaliadas foram: indice de área de estruturas reprodutivas, eficiência de interceptação de RFA e coeficiente de extinção dessas estruturas. A interceptação de RFA aumentou com a elevação do volume das estruturas reprodutivas. A eficiência de interceptação de RFA pelas estruturas reprodutivas variou de 45 a $80 \%$, sendo maior no híbrido Hyola 61 e na maior dose de $N$ aplicado. $O$ coeficiente de extinção de estruturas reprodutivas foi de $0,44 \mathrm{em}$ doses não limitantes de $N$.

Palavras-chave: Brassica napus, eficiência de interceptação, coeficiente de extinção, síliqua.

\section{INTRODUCTION}

In Brazil, canola (Brassica napus L. var. Oleifera) has been studied since the late 1970, especially in Rio Grande do Sul State. At the beginning, those researches aimed general aspects of cropping, and prioritized the grain yields under different practices of management, such as arrangement of plants, sowing dates, nitrogen levels, also including tests of cultivars and hybrids. Nowadays, the expansion of the crop in other regions is necessary, as well as raising grain yield, which remains in the range of $1500 \mathrm{~kg} \mathrm{ha}^{-1}$, far below the potential of canola, which is around $4,500 \mathrm{~kg} \mathrm{ha}^{-1}$ (THOMAS, 2003). For these purposes, studies

\footnotetext{
'Departamento de plantas forrageiras e agrometeorologia, Universidade Federal do Rio Grande do Sul (UFRGS), 91540-000, Porto Alegre, RS, Brasil. E-mail: elizandrofochesatto@hotmail.com. Corresponding author.

IDepartamento de Agronomia, Universidade do Estado de Mato Grosso (UNEMAT), Tangará da Serra, MT, Brasil.

IIIDepartamento de Plantas forrageiras e Agrometeorologia, Universidade Federal do Rio Grande do Sul (UFRGS), Porto Alegre, RS, Brasil.

${ }^{\text {IV }}$ Centro Nacional de Pesquisa de Trigo, Embrapa, Passo Fundo, RS, Brasil.

vDepartamento de Plantas forrageiras e Agrometeorologia, Universidade Federal do Rio Grande do Sul (UFRGS), Porto Alegre, RS, Brasil.

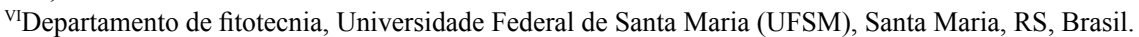


in different areas of knowledge are necessary, in particular seeking to deepen the understanding of biological processes involved in the plant growth and development. In the case of canola, understanding and quantifying the evolution of photosynthetically active radiation (PAR) interception by both leaf area and reproductive structures of plants is essential.

In general, interception of PAR, as well as photosynthesis process, occurs predominantly in leaves. This has motivated large studies to adjust parameters that relate the evolution of leaf area index (LAI) and PAR interception efficiency. In the case of canola; however, this applies only to the vegetative growth of plants, when the interception of solar radiation and photosynthesis occurs in the leaves, in a close relationship with the leaf area index. However, after flowering these processes are transferred to the reproductive structures, especially siliques, whose area index (AIRS) increases gradually (MOGENSEN et al., 1997; DIEPENBROCK, 2000). According to SHEORAN et al. (1991), the contribution of these structures in the photosynthesis of canola varies from 70 to $100 \%$ from flowering to the physiological maturity of grains. Through this process, photoassimilates are used in maintaining the physiological needs of plants and in the grain filling (MOGENSEN et al., 1997).

In literature, studies involving the area index of reproductive structures (AIRS) are very few and generally involve winter canola. In this sense, JUSTES et al. (2000) observed that AIRS increased by the end of grain filling, under three nitrogen levels $\left(0,135\right.$ and $\left.270 \mathrm{~kg} \mathrm{ha}^{-1}\right)$, and that the higher dose of $\mathrm{N}$ had a higher index, in the order of $2.6\left(\mathrm{~m}^{2} \mathrm{~m}^{-2}\right)$. Using $\mathrm{N}$ doses of 0,100 and $200 \mathrm{~kg} \mathrm{ha}^{-1}$ GAMMELVID et al. (1996) have obtained AIRS around $4\left(\mathrm{~m}^{2} \mathrm{~m}^{-2}\right)$ for the higher level of nutrient. Thus, it can be inferred that, in winter canola, the increment of available $\mathrm{N}$ tends to increase the area index of reproductive structures. Conversely, little is known in this regard in spring canola, as well as for different genotypes.

Results obtained by NIED (2013) indicate the importance of studies in determining the extinction coefficient $(\mathrm{k})$ of solar radiation by reproductive structures of the canola, in environmental conditions of Brazil, considering its importance for crop modeling and because there are no studies on this aspect for spring canola. In this subject, two studies were reported in the literature, aiming to determine the extinction coefficient of reproductive structures for winter canola. In one of those studies, ANDERSEN et al. (1996) reported an average coefficient of 0.5 . In the other FRAY et al. (1996), quantified the k coefficient for two genotypes, being one with conventional architecture and another with erect siliques. In this study, when the angle of siliques insertion ranged from $20^{\circ}$ to $25^{\circ}$ (conventional) the extinction coefficient varied from 0.45 to 0.50 , whereas, with upright siliques the average $\mathrm{k}$ was 0.40 . Therefore, more upright siliques tend to permit a higher penetration of solar radiation to layers located at the bottom of the canopy, which may provide more photosynthesis, thereby increasing the grain weight and the grain yield (MOGENSEN et al., 1997; NIED, 2013).

In this context, the objective of this study was to parameterize the interception of photosynthetically active radiation (PAR) by the reproductive structures of canola, for different levels of nitrogen applied and hybrids.

\section{MATERIALS AND METHODS}

Two field experiments were conducted in 2011 and 2014, in the Embrapa Wheat (Embrapa Trigo), in Passo Fundo ( $28^{\circ} 13$ '36”S, 52 24' 10" W, and $692 \mathrm{~m}$ alt.) and in Coxilha (28 $11^{\circ}$ ' 40"S, $5210^{\prime}$ 20 "W, and $689 \mathrm{~m}$ alt.) in the Planalto Médio region of Rio Grande do Sul State, Brazil. In 2011, the experiment had different hybrids of spring canola, while in 2014, different doses of nitrogen were applied in top dressing, using only one hybrid.

The experimental design was a randomized block with four replications. In 2011, the treatments were the Hyola 61 and Hyola 432 hybrids. The adopted row spacing was $20 \mathrm{~cm}$, with a final density of 40 plants per square meter. At the crop sowing, the soil was fertilized with 80,80 and $15 \mathrm{~kg} \mathrm{ha}^{-1}$ of $\mathrm{P}_{2} \mathrm{O}_{5}$, $\mathrm{K}_{2} \mathrm{O}$, and nitrogen $(\mathrm{N})$, respectively. Two doses of 48 and $45 \mathrm{~kg} \mathrm{ha}^{-1}$ of $\mathrm{N}$ were applied in top dressing, being one dose in the vegetative growth and the other in the reproductive period. In addition, $48 \mathrm{~kg} \mathrm{ha}^{-1}$ of sulfur were also applied at sowing. In 2014, the treatments consisted of five nitrogen doses, applied in top dressing: 10, 20, 40, 80 and $160 \mathrm{~kg} \mathrm{ha}^{-1}$, and the hybrid was Hyola 61 . The row spacing was $0.34 \mathrm{~cm}$ with a final density of 40 plants per square meter. At sowing, the fertilization consisted of $250 \mathrm{~kg} \mathrm{ha}^{-1}$ of the 4-20-20 formula (N-P-K, respectively). In top dressing, urea and ammonium sulfate were used, according to the $\mathrm{N}$ doses for each treatment. The doses of 80 and $160 \mathrm{~kg}$ $\mathrm{ha}^{-1}$ of $\mathrm{N}$ were split and applied in two and three times, respectively, throughout the plant vegetative growth. Sowing was carried out on $05 / 07 / 2011$ and 04/29/2014.

The area of reproductive structures (siliques and stems) was determined only in the 
experiment with different doses of $\mathrm{N}$, in 2014. For this, two paired plants were collected, on two dates: $09 / 08 / 2014$ and $09 / 22 / 2014$, when the plants had $10 \%$ of siliques with dark-colored grains. Immediately after collection, plants were taken to the laboratory where the siliques were separated from stems, to determine the area of siliques and stems, through an optical planimeter model LI 3000 (LI-COR, Lincoln, USA). With the area of siliques and stems, the area index of reproductive structures (AIRS) was calculated by the equation:

$A I R S=(A S) /(S)$

where AIRS is the area index of the reproductive structures, AS is the area of the reproductive structures of each plant $\left(\mathrm{m}^{2}\right)$ and $\mathrm{S}$ is the surface area occupied by the one plant $\left(\mathrm{m}^{2}\right)$.

The photosynthetically active solar radiation intercepted by the reproductive structures (PARi) was calculated in both experiments (2011 and 2014). For this, measurements were taken with a set of bars, containing five sensors of amorphous silicon in each bar, spaced at $20 \mathrm{~cm}$. They have been connected to a multiplexer of channels, which was connected to a datalogger Campbell, model CR1000. Before installation, each bar was calibrated with an AccuPar ceptometer, Decagon Devices, in 2011, and by a quantum sensor, model Sp-110, Apogee, in 2014. Readings were taken every 30 s, while their averages were calculated and stored every $15 \mathrm{~min}$.

The incident PAR on the crop canopy (PARinc) was measured with two sensor bars, located just above the plants, in 2011, and with a quantum sensor, Sp-110 model, located by $100 \mathrm{~m}$ far from the experiment, in 2014. The transmitted RFA (PARtr) by the reproductive structures of canola (stems and siliques) was measured with two sensor bars in each hybrid (Hyola 61 and Hyola 432) in 2011. In the experiment of $\mathrm{N}$ doses, three bars of sensors were installed in each treatment, which were positioned just above the leaves and reproductive structures, in a transverse direction to the plant lines. In 2011, measurements were performed from the beginning of flowering to the physiological maturity and, in 2014, they were made from the end of flowering to the week prior to physiological maturity.

From daily averages of measurements, the intercepted PAR by the reproductive structures (PARi) was calculated, according to the equation:

$P A R_{i}=$ PAR inc - PAR tr

Where PAR inc is the photosynthetically active solar radiation incident on the canopy and PARtr is the photosynthetically active solar radiation transmitted by the reproductive structures.
The interception efficiency of PAR (ci) was calculated by the equation:

$\varepsilon i=P A R i / P A R$ inc

The extinction coefficient $(\mathrm{k})$ for PAR was estimated by adjusting the parameter " $b$ " of the linear regression between values of $\varepsilon i$ and AIRS, for all treatments, in accordance to the Beer's law (MONSI \& SAEKI, 1953), expressed by the equation:

$\operatorname{Ln}(1-\varepsilon i)=-k . A I R S$

where $\mathrm{K}$ is the extinction coefficient for PAR, ci is the interception efficiency by the reproductive structures and AIRS is the area index of reproductive structures. Analysis of variance was performed to results of AIRS considering a randomized complete block design with split-plots. The factors were $\mathrm{N}$ doses, in the main plots, and dates of assessment in subplots. Results of interception efficiency for PAR by the reproductive structures, obtained in 2011 (hybrids) and 2014 ( $\mathrm{N}$ levels), were subjected to analysis of variance and the averages were compared by Tukey test, at 5\% probability of error. Data from 2011 were analyzed as from the peak of maximum $\varepsilon i$ $(10 / 17 / 2014)$ when the reproductive structures are already formed and ei achieved its stabilization. For data from 2014 a regression model was fitted to describe the variation of $\varepsilon \mathrm{i}$ in response to levels of $\mathrm{N}$.

\section{RESULTS AND DISCUSSION}

There was no interaction between doses of nitrogen and dates of evaluation on the evolution of the area index of reproductive structures (AIRS). Differences among $\mathrm{N}$ levels were detected only in the evaluation of $08 / 09 / 2014$, when the lowest area index occurred in the dose of $40 \mathrm{~kg} \mathrm{ha}^{-1}$ of applied N. On the second evaluation date, there was no significant difference among $\mathrm{N}$ treatments (Table 1). Analyzing the AIRS of winter canola with different doses of $\mathrm{N}\left(0,135\right.$ and $\left.270 \mathrm{~kg} \mathrm{ha}^{-1}\right)$, JUSTES et al. (2000) observed an increase of the index up to the end of grain filling for the three $\mathrm{N}$ levels, reaching $2.6 \mathrm{~m}^{2} \mathrm{~m}^{-2}$ with maximum dose of $\mathrm{N}$, in a density of 60 plants per square meter. In a study of GAMMELVIND et al. (1996), also in irrigated winter canola, with three levels of applied $\mathrm{N}\left(0,100\right.$ and $\left.200 \mathrm{~kg} \mathrm{ha}^{-1}\right)$ and a density of 106 plants per square meter, the AIRS was around $4 \mathrm{~m}^{2} \mathrm{~m}^{-2}$ in the maximum dose of the nutrient.

Results from this study did not follow the same logic reported by GAMMELVIND et al. (1996) and JUSTES et al. (2000), which can be attributed to the lower density of plants (mean of 33 plants per square meter) in comparison to those experiments. 
Table 1 - Index area of reproductive structures - siliques and stems (AIRS) of canola under different levels of nitrogen $\mathrm{N}\left(\mathrm{kg}^{-1} \mathrm{~h}^{-1}\right)$ applied in top dressing, in two evaluation dates. Coxilha, RS, Brazil. 2014.

\begin{tabular}{|c|c|c|c|}
\hline \multirow{2}{*}{$\begin{array}{l}\text { Doses } \\
\text { Nitrogen }\end{array}$} & \multicolumn{3}{|c|}{ 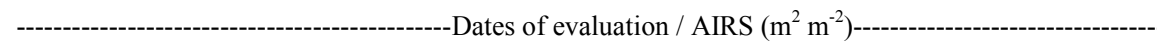 } \\
\hline & $08 / 09 / 2014$ & $22 / 09 / 2014$ & Average \\
\hline 10 & $2.90 \mathrm{a} \mathrm{A}^{*}$ & 1.98 a $\mathrm{A}$ & 2.44 \\
\hline 20 & $2.47 \mathrm{a} \mathrm{A}$ & 1.89 a $\mathrm{A}$ & 2.22 \\
\hline 40 & $1.52 \mathrm{~b} \mathrm{~A}$ & $2.22 \mathrm{a} \mathrm{A}$ & 2.37 \\
\hline 80 & $3.11 \mathrm{a} \mathrm{A}$ & $1.94 \mathrm{a} \mathrm{A}$ & 2.53 \\
\hline 160 & $3.04 \mathrm{a} \mathrm{A}$ & $1.99 \mathrm{a} \mathrm{A}$ & 2.52 \\
\hline Average & 2.60 & 2.01 & \\
\hline CV (\%) & 31 & 22 & \\
\hline
\end{tabular}

*Small letters represent comparisons among doses of applied N, on columns, and capital letters represent comparisons between dates of evaluations for each treatment, on lines, by the Tukey test at $5 \%$ probability of error; CV = coefficient of variation.

Other factors could also have affected AIRS, as the instability of this variable due to the low population of plants, the indeterminate growth habit and high morphological plasticity of the canola plants, which allows them a high capability of adjustment to variations in density of plants into the canopy (KRÜGER et al., 2011). Furthermore, the occurrence of frost in the reproductive period could also have contributed to the homogenization of the AIRS, due to both abortion and lesions of siliques larger than $4 \mathrm{~cm}$ in length, which characterizes damages by freezing, as a consequence of frost.

Interception efficiency ( $\varepsilon$ i) of PAR by the reproductive structures had sharp increase until near the end of the canola flowering, reaching values of 0.7 and 0.8 for the Hyola 61 and Hyola 432 hybrids, respectively (Figure 1a). These results are in agreement with results of DIEPENBROCK (2000), who reported that $\varepsilon i$ increased with increasing in AIRS. From the end of flowering to the physiological maturity ei remained stable, around 70 and $80 \%$ in the Hyola 432 and Hyola 61 hybrids, respectively. Comparing these genotypes, it was reported that the interception efficiency of PAR was higher in Hyola 61, on the order of 0.75 , compared to Hyola 432, which had an efficiency on the order of 0.68 . The higher $\varepsilon i$ in Hyola 61 can be associated with denser reproductive structures than in Hyola 432. These results complement observations made by NIED et al. (2014), who observed higher AIRS and higher dry matter siliques in Hyola 61 compared to Hyola 432 hybrid.

The interception efficiency (ci) of photosynthetically active radiation (PAR) by the reproductive structures had different responses to doses of applied N (Figure 1b). The dose of 160kg ha $^{-1}$ of $\mathrm{N}$ promoted the highest interception efficiency of PAR among treatments, remaining above $70 \%$ and with little variation in the entire period, suggesting a denser composition of reproductive structures (Figures $1 \mathrm{~b}$ and 1c). Doses of 10 and $20 \mathrm{~kg} \mathrm{ha}^{-1}$ provided smaller PAR values of interception efficiency, between $45 \%$ and $55 \%$. Moreover, smaller nitrogen doses also provided a high oscillation in PAR interception (Figure 1b), indicating a less dense composition of reproductive structures. Data of $\varepsilon \mathrm{i}$ allowed to adjust a linear equation $(\varepsilon \mathrm{i}=0.0015 \mathrm{~N}+$ $0.5524 ; \mathrm{R}^{2}=0.88$ ), indicating that RFA interception by the reproductive structures increased, but not stabilized, as function of the $\mathrm{N}$ doses used in this study. Results of interception efficiency obtained with the two higher doses of applied $\mathrm{N}$ are equivalent to values obtained by CHARTIER et al. (1983) and FRAY et al. (1996), between 70 and $80 \%$, while the lowest doses of $\mathrm{N}\left(10\right.$ and $\left.20 \mathrm{~kg} \mathrm{ha}^{-1}\right)$, provided values of ei between 45 and 55\%. This response can in part be attributed to limitations of $\mathrm{N}$ for photosynthesis (KAEFER et al., 2014), which results in a low production of reproductive structures, in comparison to higher levels of nitrogen. Thus, canola plants may increase the production of assimilates if they are well supplied in $\mathrm{N}$, so producing more siliques.

Considering all doses of applied $\mathrm{N}$ and the two dates the evaluation, average extinction coefficient for photosynthetically active radiation (PAR) of reproductive structures was 0.44 (Figure 2a). This value is $12 \%$ lower than that reported in winter canola by ANDERSEN et al. (1996) and FRAY et al. (1996), also for the reproductive structures, which was 0.5 . However, it is $9 \%$ higher than that reported by FRAY et al. (1996) for winter canola with more upright siliques.

Ciência Rural, v.46, n.10, out, 2016. 


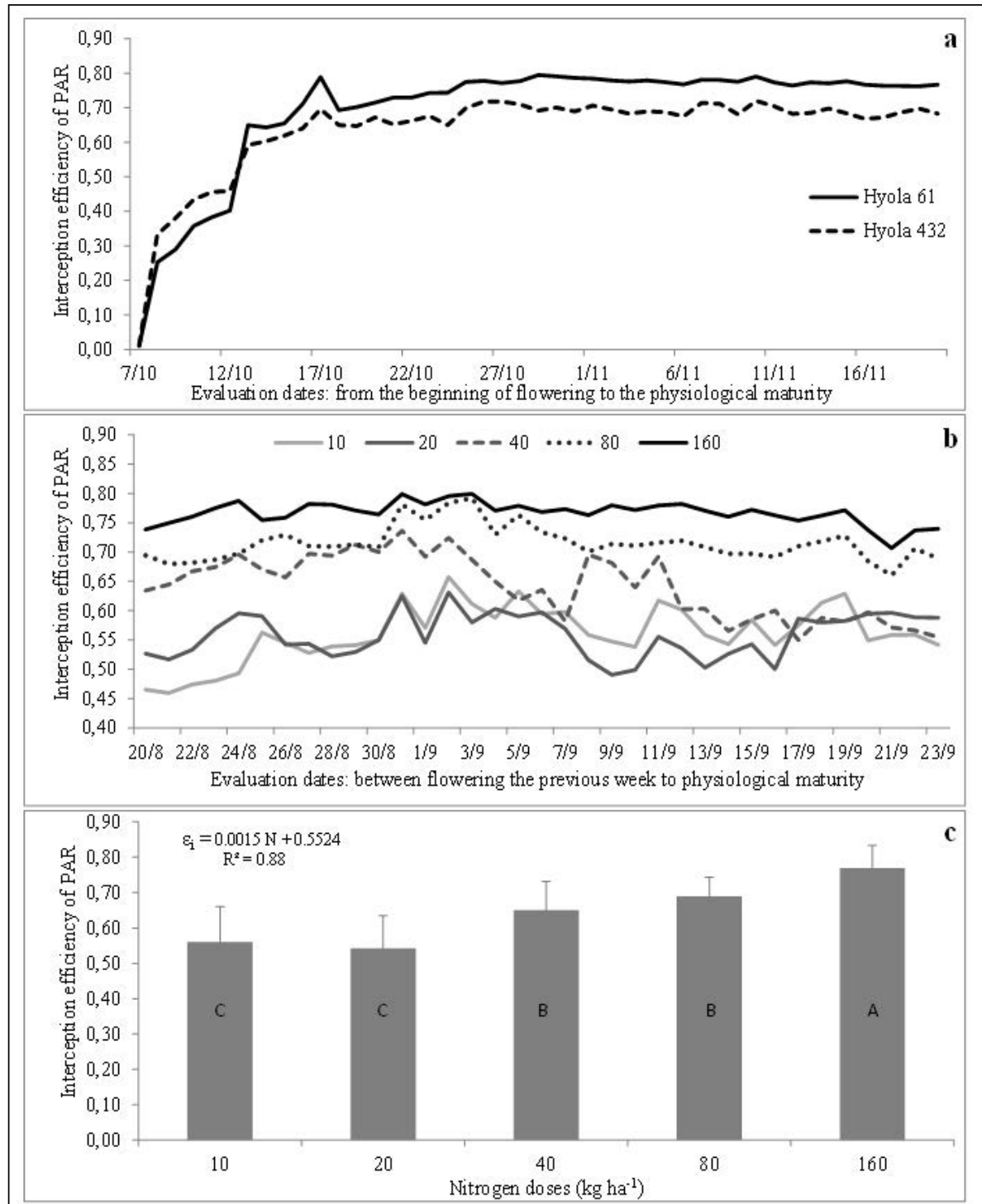

Figure 1 - Efficiency interception of photosynthetically active radiation ( $\varepsilon i$ ) by reproductiv estructures of two canola hybrids, in Passo Fundo, RS, Brazil, 2011(a), and under different nitrogen doses $(10,20,40,80,160 \mathrm{~kg}$ ha-1) in Coxilha, RS, Brazil, 2014 (b ,c).

Means followed by the same letter do not differ among doses of $\mathrm{N}$, by the Tukey test at $5 \%$ probability of error.

When considering only the two higher doses of applied N, 80 to $160 \mathrm{~kg} \mathrm{ha}^{-1}$ (Figure 2b), the extinction coefficient for PAR was 0.46 , somewhat higher than the average coefficient for all doses of $\mathrm{N}$ together (Figure 2a). Even so, this value is slightly lower than that reported by ANDERSEN et al. (1996) and FRAY et al. (1996) for conventional winter canola genotypes, but greater than the coefficient reported by FRAY et al. (1996) for a genotype with more upright siliques.
This shows that, for spring canola cultivated in conditions of southern Brazil, there is more interception of PAR by reproductive structures in non-limiting levels of available nitrogen, due to a higher production of reproductive structures, than for low levels of nitrogen. Moreover, the wide spreading of points, observed in figure $2 \mathrm{a}$, when considered all nitrogen levels, shows low uniformity in the morphology of canola canopies when subjected to limiting levels 


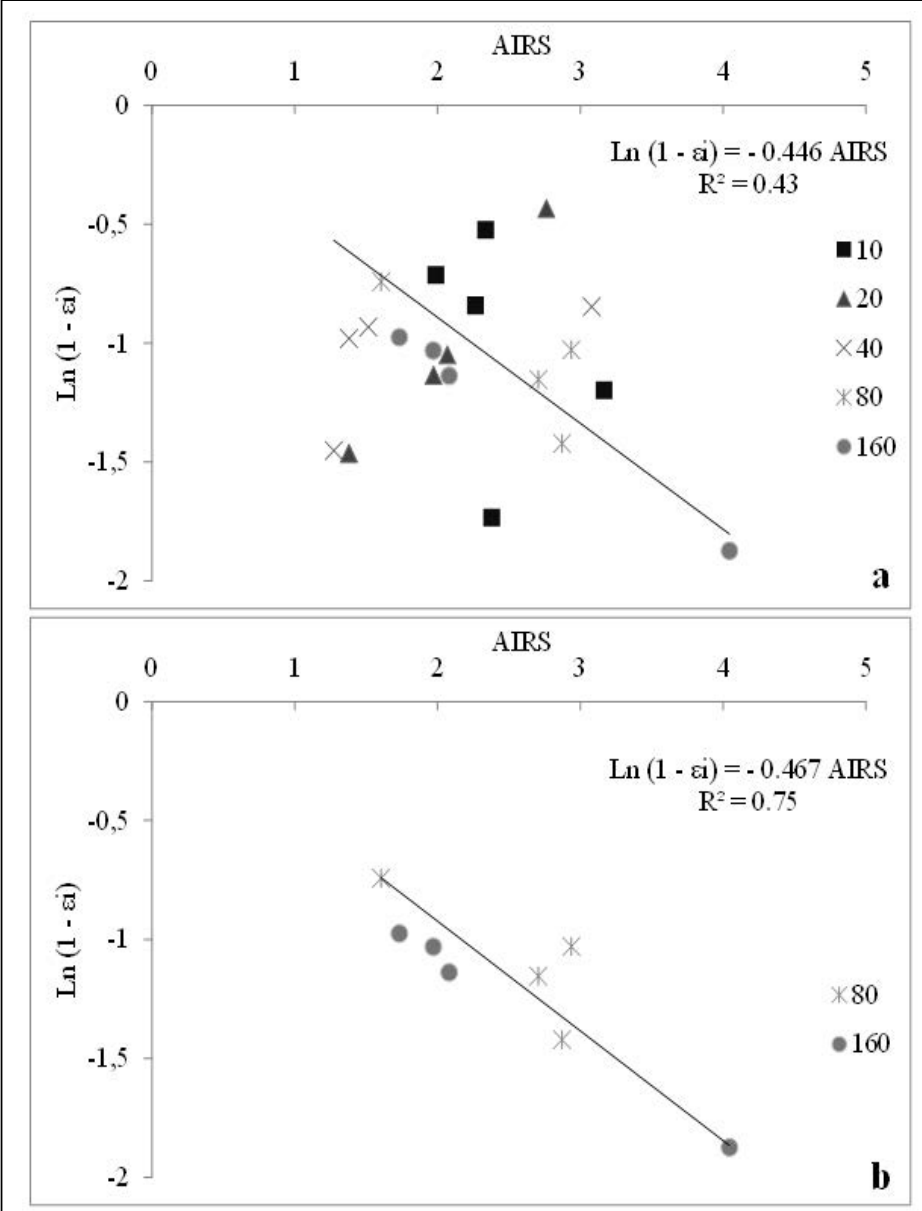

Figure 2 - Averaged extinction coefficient (k) for photosynthetically active radiation (PAR), represented by the slope of the linear regression equation between the natural logarithm of the not intercepted PAR [Ln (1-ei)] and the area index of reproductive structures (AIRS), for all different doses of applied nitrogen(a) and for the $\mathrm{N}$ doses of 80 and $160 \mathrm{~kg} \mathrm{ha}^{-1}(\mathrm{~b})$, in two evaluation dates. Coxilha, RS, Brazil, 2014.

of $\mathrm{N}$. In contrast, figure $2 \mathrm{~b}$ shows that there was a more uniform morphology of plants at the highest levels of $\mathrm{N}$, applied in coverage, which allowed a better fit in estimating the extinction coefficient for PAR of the reproductive structures of canola.

\section{CONCLUSION}

In spring canola crops, hybrids with dense reproductive structures present greater efficiency and uniformity in intercepting the photosynthetically active radiation. Not limiting levels of available nitrogen to plants allow to increase the efficiency and uniformity of PAR interception by the reproductive structures of spring canola.

\section{ACKNOWLEDGEMENT}

To the Fundação de Amparo à Pesquisa do Estado do Rio Grande do Sul (FAPERGS), the Conselho Nacional de Desenvolvimento Científico e Tecnológico ( $\mathrm{CNPq}$ ) and the Coordenação de Aperfeiçoamento de Pessoal de Nível Superior (CAPES) for granting scholarships. To the Universidade Federal do Rio Grande do Sul (UFRGS), and Embrapa Wheat for support, the FINEP - Inovação e Pesquisa and the Universidade do Estado do Mato Grosso (UNEMAT) for support.

\section{REFERENCES}

ANDERSEN, M.N. et al. The effects of drought and nitrogen on light interception, growth and yield of winter oilseed rape. Acta Agriculturae Scandinavica Section B-Soil and Plant Science, Copenhagen, v.46, n.1, p.55-67, 1996. Available from: <http://www.tandfonline.com/doi/ 
abs/10.1080/09064719609410947>. Accessed: Nov 20, 2015. doi: $10.1080 / 09064719609410947$.

CHARTIER, M. et al. Bilan radiatif d'un couvert de colza. In: LE COLZA:CONGRES INTERNATIONAL, 6., 1983, Paris, FRA. Proceedings... [Paris, 2003].(p.154-165).

DIEPENBROCK, W. Yield analysis of winter oilseed rape (Brassica napus L.): a review. Field Crops Research, Amsterdam, v.67, p.35-49, 2000. Available from: <http://www.sciencedirect. com/science/article/pii/S0378429000000824>. Accessed: Nov 20, 2015. doi: 10.1016/S0378-4290(00)00082-4.

FRAY, M.J. et al. Physiological assessment of apetalous flowers and erectophile pods in oilseed rape (Brassica napus). Journal of Agricultural Science, Cambridge, v.127, n.02, p.193-200, 1996. Available from: <http:// journals.cambridge.org/action/displayAbstract?fromPage $=$ online\&aid $=4804888 \&$ next $=$ true \&jid=AGS\&volumeId= 127\&issueId $=02>$. Accessed: Out. 15, 2015 doi: 10.1017/ S0021859600077972.

GAMMELVIND, L.H. et al. Photosynthesis in leaves and siliques of winter oilseed rape (Brassica napus L). Plant and Soil, Holanda, v.186, n.2, p.227-236, 1996. Available from: $<$ http://link. springer.com/article/10.1007\%2FBF02415518>. Accessed: Nov 15, 2015. doi: 10.1007/BF02415518.

JUSTES, E. et al. Effect of crop nitrogen status and temperature on the radiation use efficiency of winter oilseed rape. European Journal of Agronomy, Amsterdam, v.13, p.165-177, 2000. Available from: <http://www.sciencedirect.com/science/article/ pii/S1161030100000721>. Accessed: Nov 8, 2015. doi: 10.1016/ S1161-0301(00)00072-1.

KAEFER, J.E. et al. Grain yield and yield components in canola according to nitrogen sources and rates. Pesquisa Agropecuária Brasileira, Brasília, v.49, p.273-280, 2014. Available from: <http://www.scielo.br/scielo php?script $=$ sci_arttext\&pid $=$ S0100-204X2014000400273 > . Accessed: Oct 15, 2015. doi: 10.1590/S0100204X2014000400005.
KRÜGER, C.A.M.B. et al. Heritability and phenotypic correlation of characters related to grain yield and morphology of canola. Pesquisa Agropecuária Brasileira, Brasília, v.46, n.12, p.16251632, 2011. Available from: <http://seer.sct.embrapa.br/index. php/pab/article/view/10874/6719>. Accessed: Sept 28, 2015. doi: 10.1590/S0100-204X2011001200007.

MOGENSEN, V.O. et al. Pod photosynthesis and drought adaptation of field grown rape (Brassica napus). European Journal of Agronomy, Amsterdam, v.6, p.295-307, 1997. Available from: <http://www.sciencedirect.com/science/article/ pii/S1161030196020527>. Accessed: May 25, 2015. doi: 10.1016/ S1161-0301(96)02052-7.

MONSI, M.; SAEKI, T. The light factor in plant communities and its significance for dry matter producton. Japanese Journal of Botany, Tokyo, v.14, p.22-52, 1953.

NIED, A.H. et al. Eficiência de interceptação de radiação solar por estruturas vegetativas e reprodutivas da canola. In: SIMPÓSIO LATINO AMERICANO DE CANOLA, 2014, Passo Fundo, RS. Anais... Passo Fundo, 2014. Available from: <http://www.cnpt. embrapa.br/slac/cd/pdf/Astor NIED>. Accessed: Apr. 10, 2015

NIED, A.H. Parâmetros bioclimáticos e resposta da canola ao ambiente físico. 2013. 135f. Tese (Doutorado Fitotecnia/ agrometeorologia) - Programa de Pós-Graduação em Fitotecnia, Faculdade de Agronomia, Universidade Federal do Rio Grande do Sul, Porto Alegre, RS. Available from: < http://www.lume.ufrgs.br/ handle/10183/80779>. Accessed: Apr 3, 2015.

SHEORAN, I.S. et al. In vivo fixation of $\mathrm{CO}_{2}$ by attached pods of Brassica-Campestris L. Annals of Botany, London, v.67, n.5, p.425-428,1991. Available from: <http://aob.oxfordjournals.org/ content/67/5/425.abstract $>$. Accessed: Apr 25, 2015. doi: 10.1093/ oxfordjournals.aob.a088177.

THOMAS, P. Canola: grower's manual. Winnipeg: Canola Council of Canada. 2003. Available from: <http://www. canolacouncil.org/crop-production/canola-grower's-manualcontents/chapter-2-canola-varieties/canola-varieties\#brassica>. Accessed: Mar. 05, 2015. 